\title{
Influence of Ammonia Contamination on HT-PEM Fuel Cell Platinum Catalyst
}

A. Dushina, D. Schonvogel, Y. Fischer, J. Büsselmann, A. Dyck, P. Wagner anastasia.dushina@dlr.de PRiME 2020, I01D-2339, 08.10.20

DLR Institute of Networked Energy Systems Oldenburg, Germany
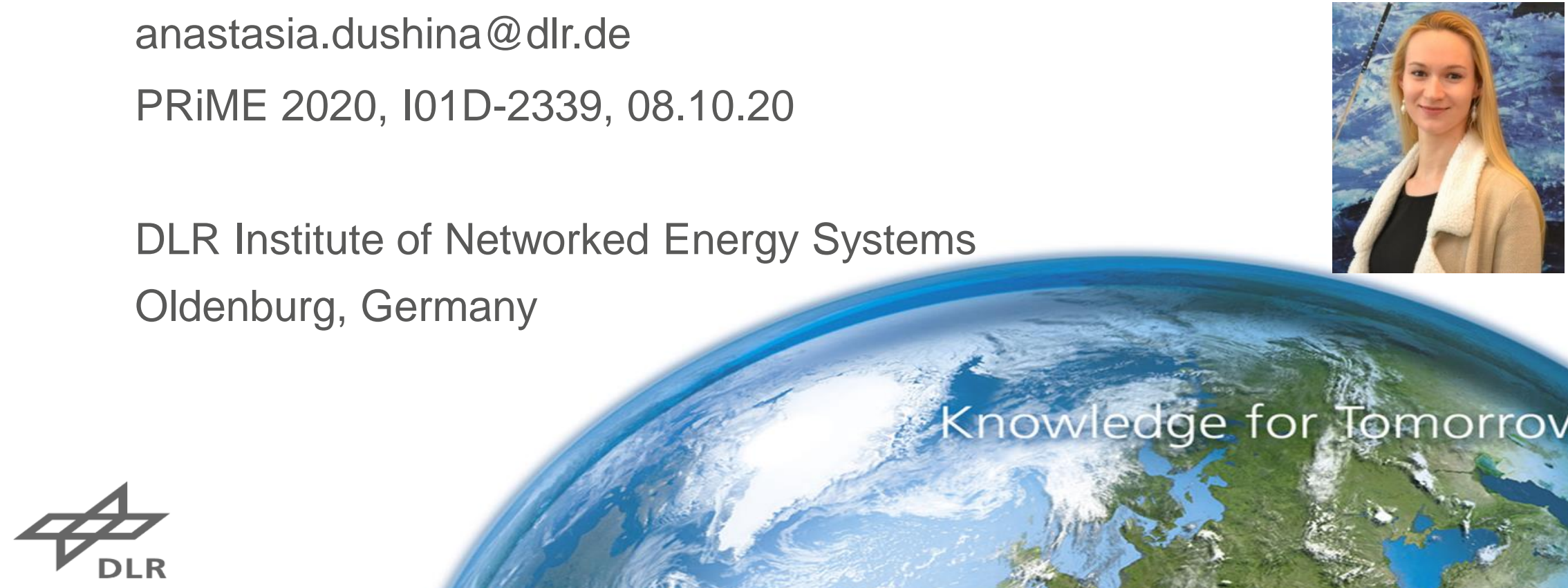


\section{Outline}

- Introduction of the Group

- Motivation \& Projects Goals

- Contamination in Fuel Cell: Sources and Species

- Strategies \& Experiments

- MEA Characterization

- RRDE Measurements

- Summary

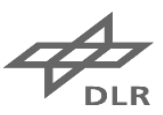




\section{Research on Fuel Cells}

- DLR Institute of Networked Energy Systems

- Development of technologies and concepts for energy supply based on renewables

- Department Fuel Cells

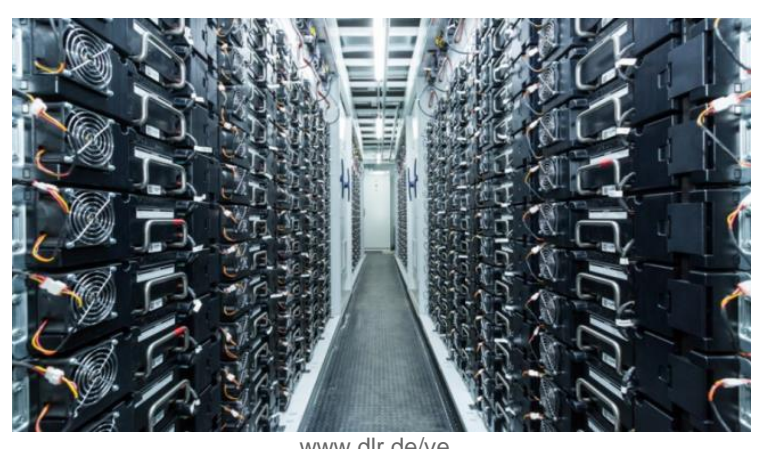

www.dlr.de/ve

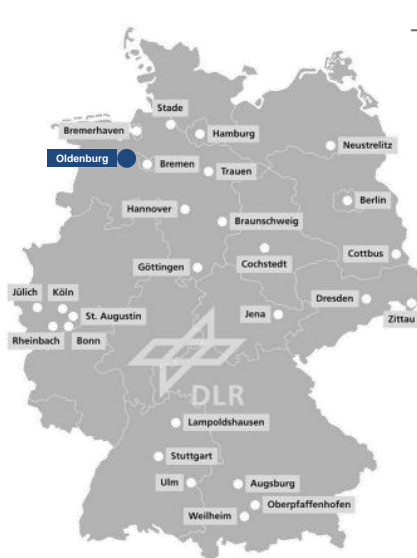

in progress
- DLR Institute of Engineering Thermodynamics

- Research into the field of efficient energy storage systems

- Department Electrochemical Energy Technology

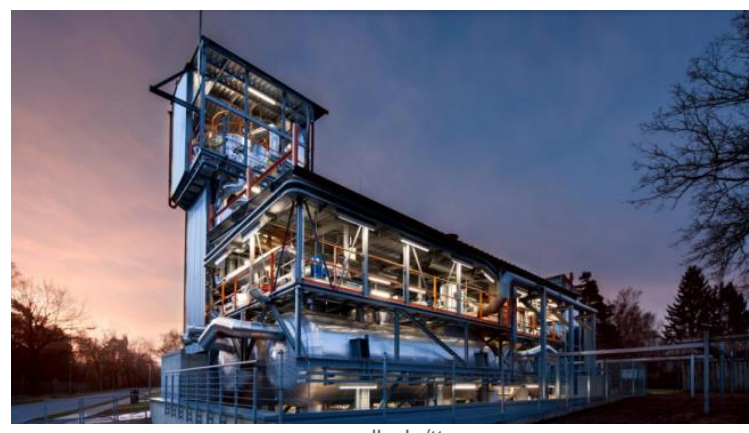

www.dlr.de/tt

\section{The group Characterisation merges into the group HT-PEM.}

- Investigation of aging processes in (LT- and HT-PEM) fuel cells and development of cell components.

- Bipolar plates, membranes, catalysts, electrodes, membrane electrode assemblies, single cells and short stacks. 


\section{Project „HAIMa“"}

$\mathrm{H}_{2}$ and Cations-Contamination: Aging-Effects, Material and Sensor Development

Investigation of the Influence of the $\mathrm{H}_{2}$ Impurities and Corrosion Products on the Catalyst Layer

\section{Development of Stable Membrane}

Development of the Monitoring Sensor System Detecting $\mathrm{H}_{2}$ Quality at a Gas Station

Project duration:

$01.12 .16-30.06 .20$
Funding number: 03ET6098D

\section{Fraunhofer}

ISE
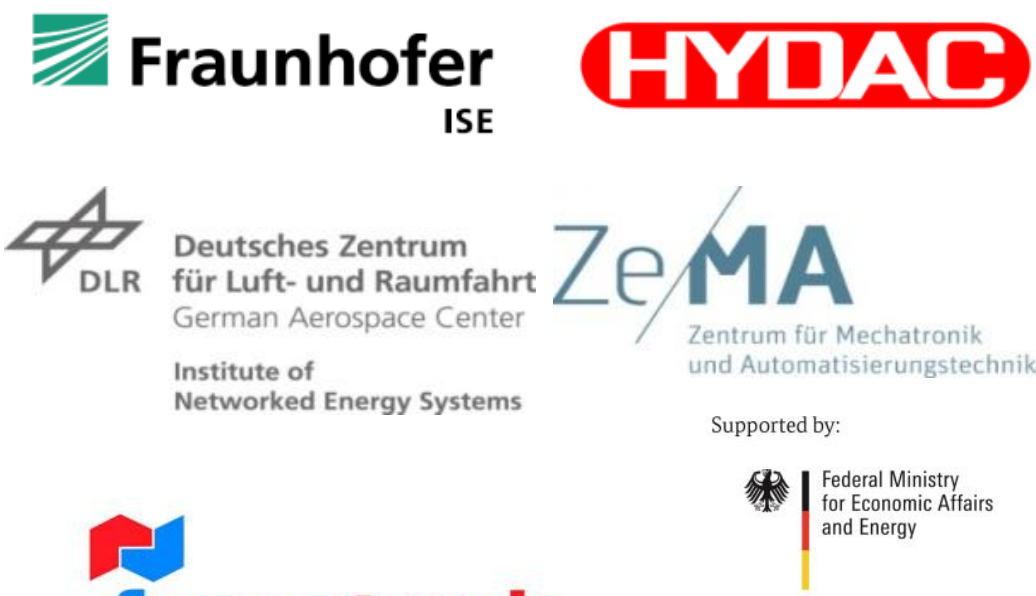

fumatech Funktionelle Membranen und Anlagentechnologie 


\section{Project „,HT-Kathodenluft II““}

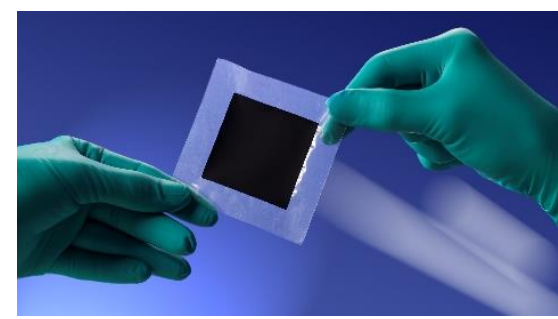

Membrane Electrode Assembly Foto: DLR

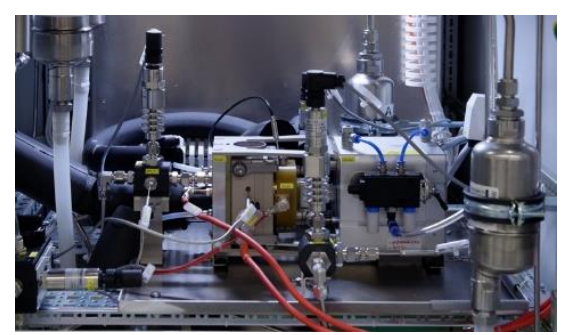

Single Cell Test Station Foto: DLR

\section{Impact of Air Impurities on HT-PEM Fuel Cell Operation}

Development of Operation Matrix Evaluation of Scenarios with Pollutants

Impurity Impact on Fuel Cell Components Electrochemical Study of Degradation

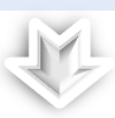

Development of Recovery Strategies

Project duration: $01.01 .18-30.09 .20$
Funding number: $19815 \mathrm{~N}$
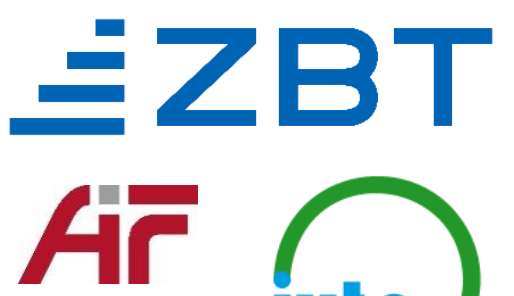

Supported by:

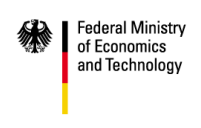

on the basis of a decision
by the German Bundestag

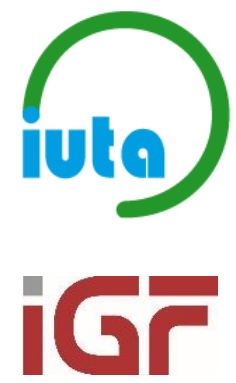

$\overbrace{\mathrm{DLR}}^{4}$ 


\section{Strategies \& Experiments}

\section{MEA}

APM-25 / Advent

Technologies SA

Harmful gas

10 ppm $\mathrm{NH}_{3}$ in

cathode air stream

Test time

$500 \mathrm{~h}$

Temperature $160{ }^{\circ} \mathrm{C}$

Current density $300 \mathrm{mAcm}^{-2}$

Stoichiometry 1.5/2.0 $\left(\mathrm{H}_{2} /\right.$ Air $)$

\section{Test bench / MEA}

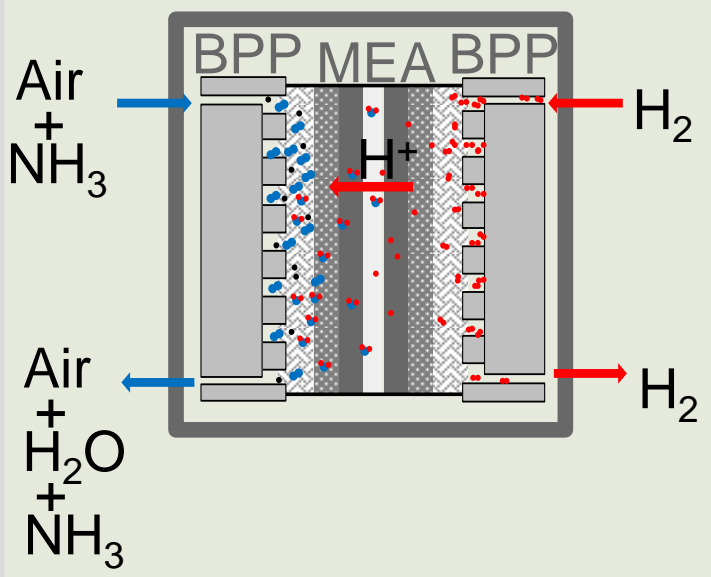

Catalyst

Pt/C HiSPEC 9100

Electrolyte

$0.5 \mathrm{M} \mathrm{H}_{3} \mathrm{PO}_{4}$

Contaminant

10 and $100 \mathrm{ppm}$ of

$\mathrm{NH}_{4} \mathrm{H}_{2} \mathrm{PO}_{4}$

Working electrode

Glassy carbon

coated with $\mathrm{Pt} / \mathrm{C}$

Counter electrode

Pt wire

Reference electrode $\mathrm{Hg} / \mathrm{HgSO}_{4}$
RRDE / Catalyst

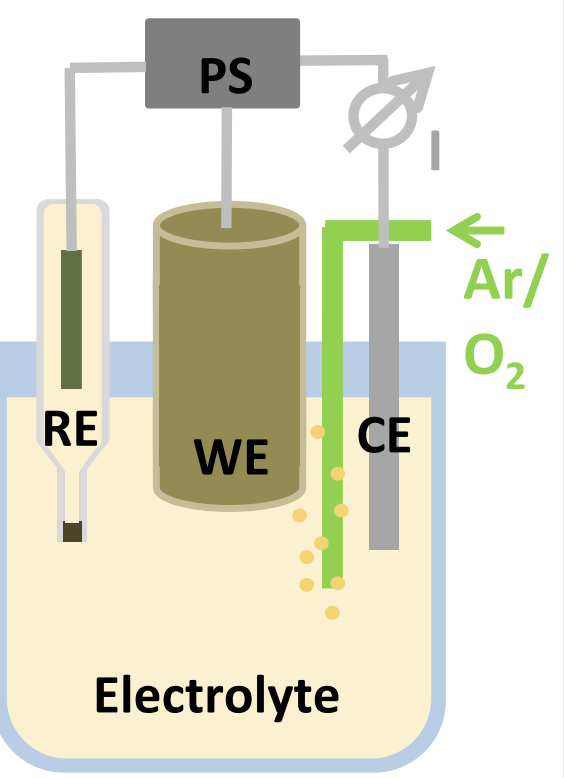

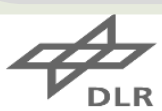




\section{MEA under HT-PEMFC conditions}

Temperature: $160{ }^{\circ} \mathrm{C}$ Current density: $300 \mathrm{mAcm}^{-2}$ Stoichiometry: 1.5/2.0 $\left(\mathrm{H}_{2} /\right.$ Air $)$
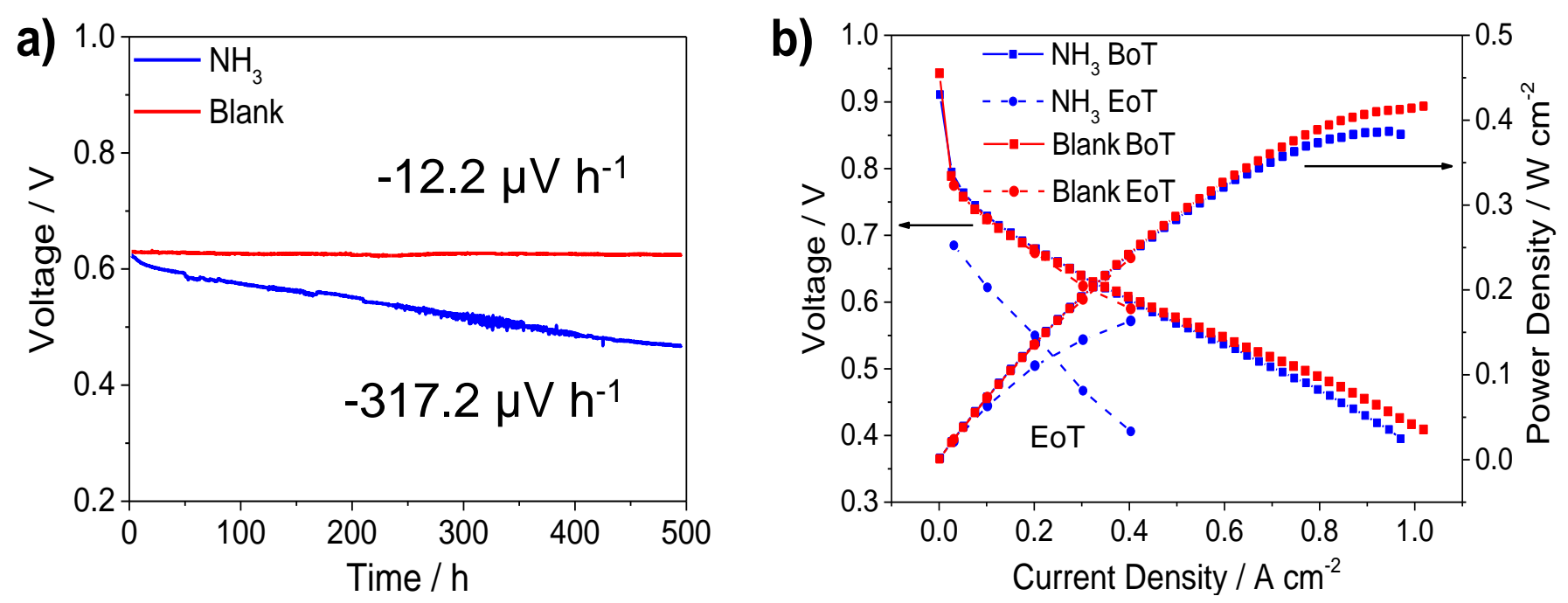

Higher degradation rate and cell performance losses in the presence of contaminant due to chemical reaction of $\mathrm{NH}_{3}$ with $\mathrm{H}^{+}$inside the membrane and catalytic layers

a) cell voltage response over time of cell operation and $b$ ) polarisation curves measured at BoT and EoT, where EoT is a quasi polarization curve measured at $0.03,0.1,0.2,0.3,0.4 \mathrm{~A} \mathrm{~cm}^{-2}$

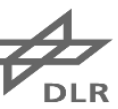




\section{Nyquist Plots and Relative Resistances of MEAs}

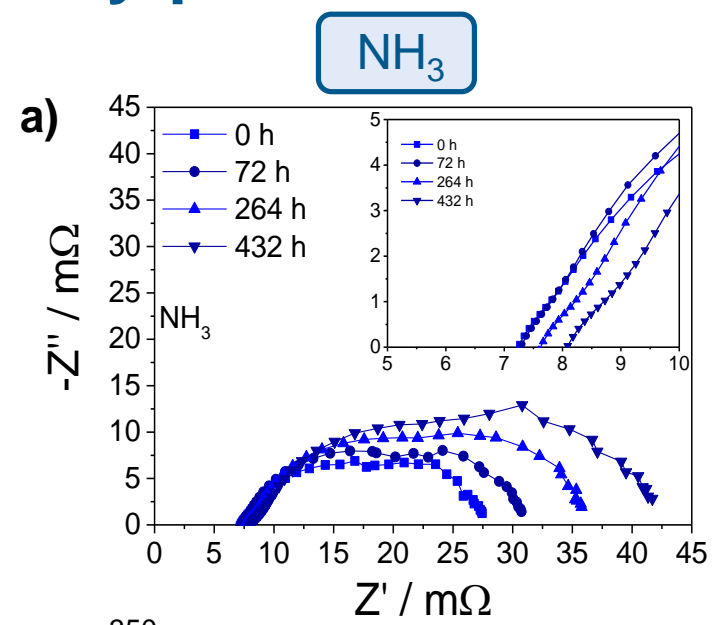

c)

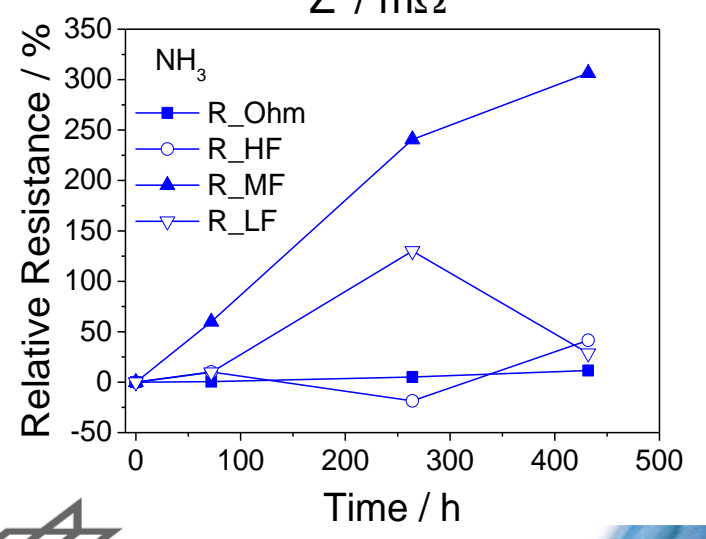

b)

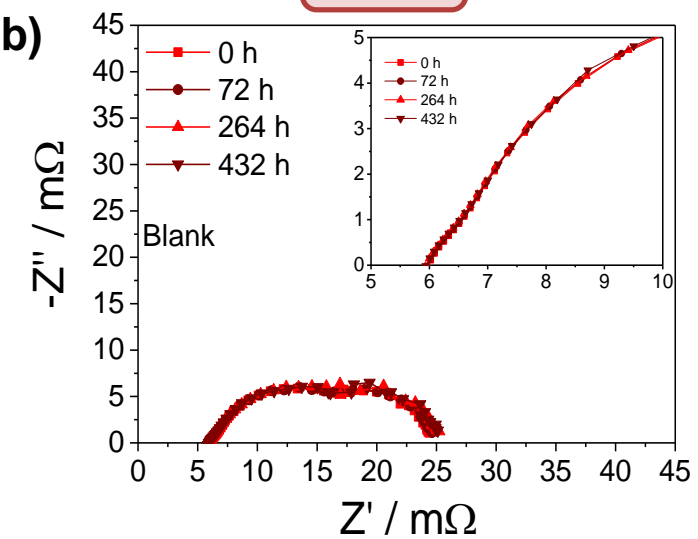

d)

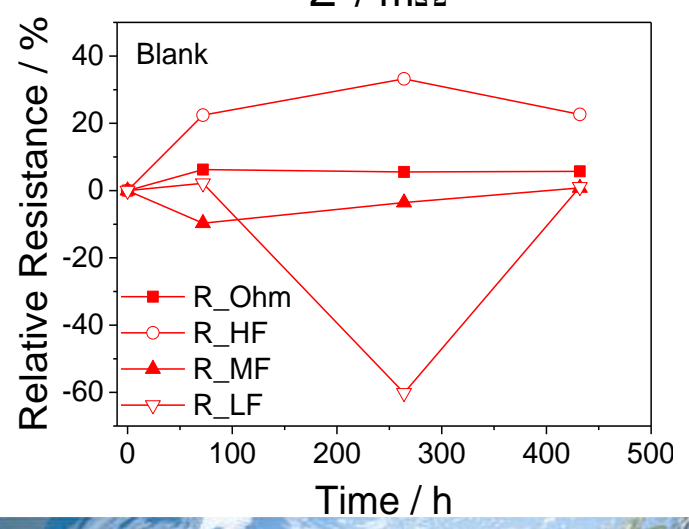

Increased polarisation, ohmic, charge and mass transfer resistances during " $\mathrm{NH}_{3}$ " operation

Significant degradation of the anode and cathode as well as the electrolyte membrane 


\section{RRDE Experiments. Electrochemical Surface Area Determination}

\section{Pt/C Catalyst $\quad 0.5 \mathrm{M} \mathrm{H}_{3} \mathrm{PO}_{4} \quad 10$ and 100 ppm of $\mathrm{NH}_{4}{ }^{+}$}
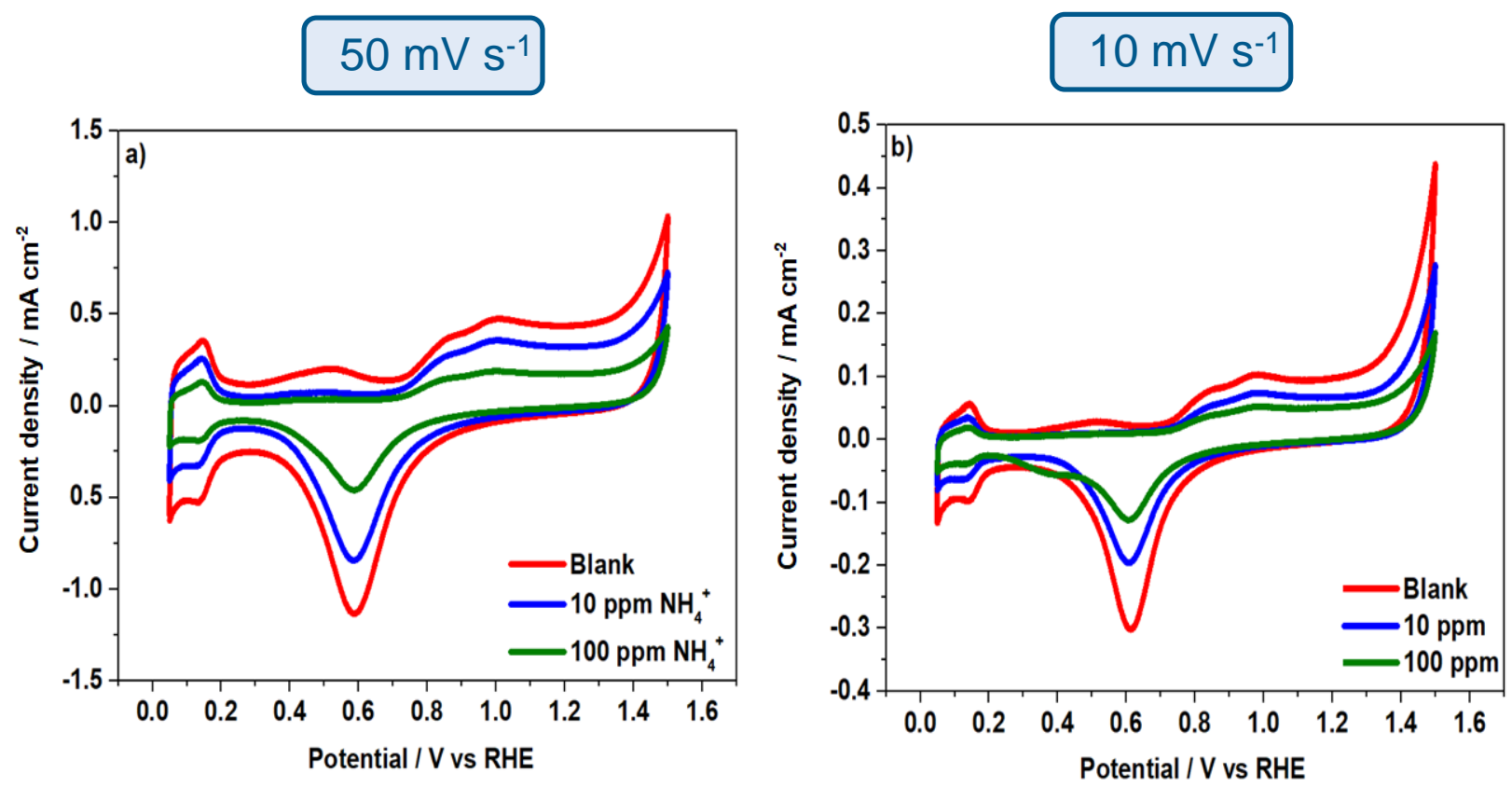

$$
\operatorname{ECSAH}_{2}=Q_{H} / v \cdot \rho \cdot \mathbf{L}_{\mathrm{Pt}}
$$

where $v$ is scan rate, $\rho$ is the charge density of hydrogen oxidation in presence of one Pt atom, $\mathrm{L}_{\mathrm{Pt}}$ is the mass of $\mathrm{Pt}$.

\begin{tabular}{|c|c|}
\hline Sample & $\begin{array}{c}\text { ECSA, } \\
\mathbf{m}^{2} \mathbf{g}_{\mathbf{P t}}{ }^{-1}\end{array}$ \\
\hline Blank & 48 \\
\hline $10 \mathrm{ppm} \mathrm{NH}_{4}^{+}$ & 27 \\
\hline $100 \mathrm{ppm} \mathrm{NH}_{4}^{+}$ & 18 \\
\hline
\end{tabular}




\section{ORR experiments}
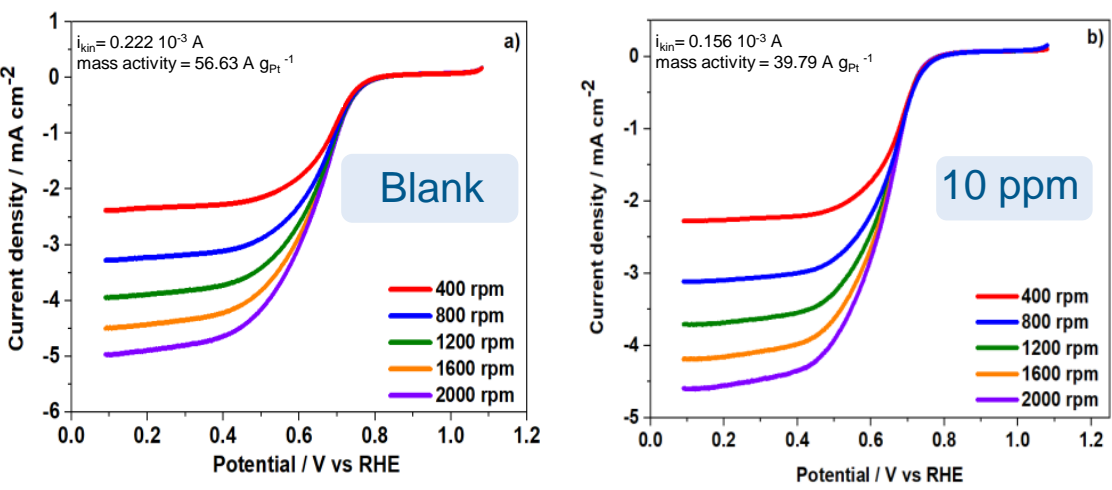

Koutecky-Levich analysis

- first order kinetics with respect to $\mathrm{O}_{2}$

- complete 4-electron reduction of $\mathrm{O}_{2}$ to water

$$
\text { slope }=\left(0.62 n F D_{\mathrm{O}}^{2 / 3} v^{-1 / 6} C_{\mathrm{O}}\right)^{-1}
$$

where $\mathrm{F}$ is Faraday's constant,
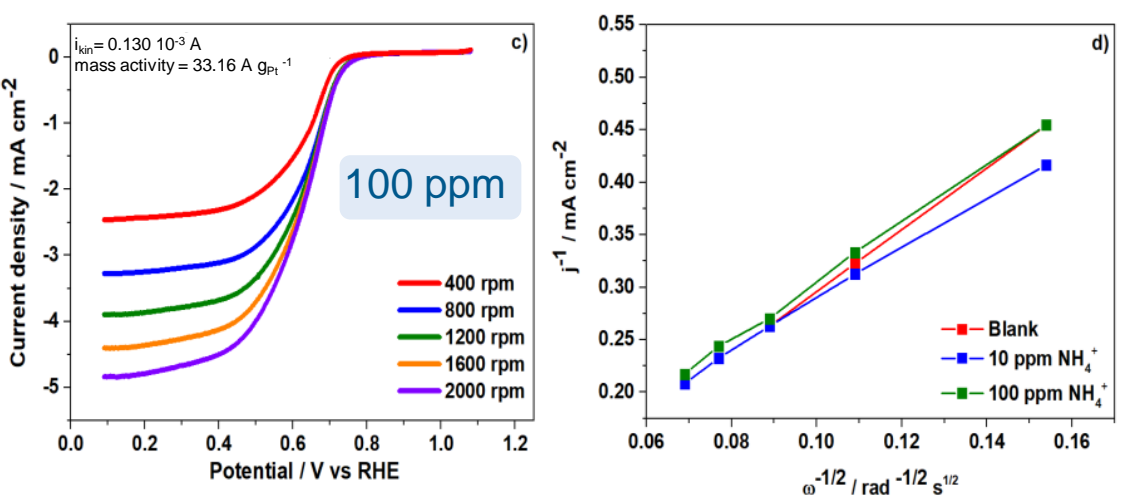

$\mathrm{D}_{\mathrm{O}}$ is the diffusivity of $\mathrm{O}_{2}$ molecule in the electrolyte, $v$ is the kinematic viscosity,

$\mathrm{C}_{\mathrm{O}}$ is the concentration of $\mathrm{O}_{2}$ in the electrolyte. 


\title{
$\mathrm{H}_{2} \mathrm{O}_{2}$ formation mechanism
}
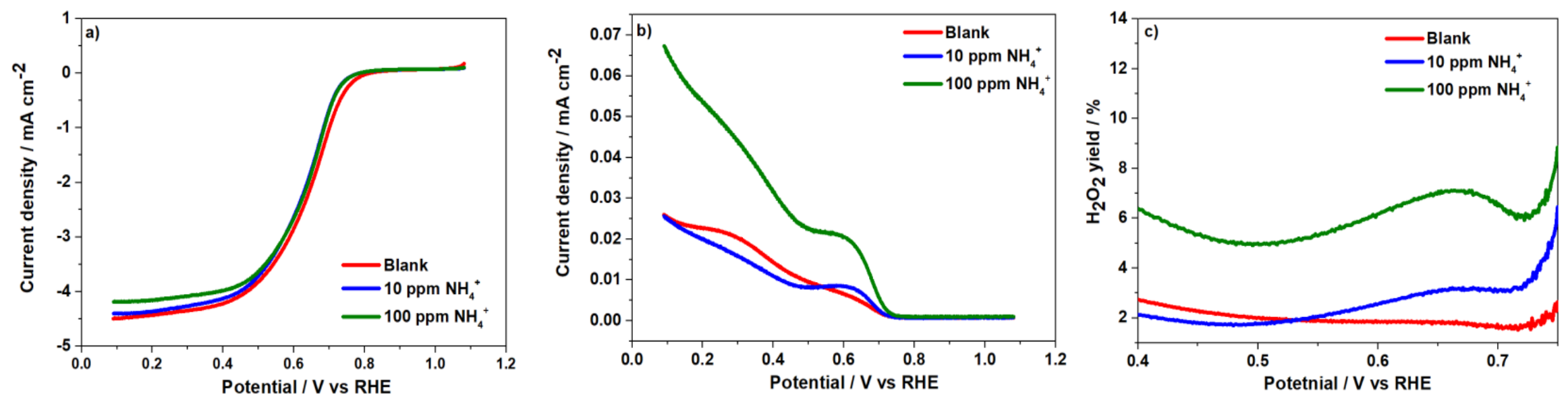

(a) ORR curves of the $\mathrm{Pt} / \mathrm{C}$ catalyst in the absence of $\mathrm{NH}_{4}{ }^{+}$and in the presence of $10 \mathrm{ppm}$ and $100 \mathrm{ppm} \mathrm{NH}{ }_{4}^{+}$in the cathodic scan at $1600 \mathrm{rpm}$ and $10 \mathrm{mV} \mathrm{s}^{-1}$; (b) $\mathrm{H}_{2} \mathrm{O}_{2}$ formation current during ORR reaction in $\mathrm{O}_{2}$-saturated $0.5 \mathrm{~mol} \mathrm{~L}^{-1} \mathrm{H}_{3} \mathrm{PO}_{4}$ at $1600 \mathrm{rpm}$, (c) relative yield of $\mathrm{H}_{2} \mathrm{O}_{2}$ in the ORR.

\author{
Increased $\mathrm{H}_{2} \mathrm{O}_{2}$ formation in the \\ presence of $100 \mathrm{ppm} \mathrm{NH}_{4}^{+}$
}




\section{Kinetic Parameters of the catalyst}

\begin{tabular}{|c|c|c|c|c|}
\hline Sample & $\begin{array}{l}\text { ECSA, } \\
m^{2} g_{P_{t}}{ }^{-1}\end{array}$ & $\begin{array}{l}\text { Kinetic Current at } \\
0.70 \text { V vs RHE, mA }\end{array}$ & $\begin{array}{l}\text { Mass Activity, } \\
\qquad \mathrm{mA} \mathrm{g}_{\mathrm{Pt}^{-1}}\end{array}$ & $\begin{array}{c}\text { Specific Activity, } \\
\mathrm{mA} \mathrm{c \textrm {cm } ^ { - 2 }}\end{array}$ \\
\hline Blank & 48 & 0.222 & 56.63 & 4.6 \\
\hline $10 \mathrm{ppm} \mathrm{NH}_{4}^{+}$ & 27 & 0.156 & 39.79 & 5.7 \\
\hline $100 \mathrm{ppm} \mathrm{NH}_{4}^{+}$ & 18 & 0.130 & 33.16 & 7.2 \\
\hline
\end{tabular}

- Lower ECSA

- Reduced kinetic current

- Decreased mass activity
Significant degradation of catalyst performance in the presence of ammonia 


\section{Summary}

- HT-PEM fuel cell performance degradation equal to $-317.2 \mu \mathrm{V} \mathrm{h}-1$ during cell operation with poisoned cathode air

- enlarged charge transfer resistances of both electrodes and a highly affected membrane in the presence of $\mathrm{NH}_{3}$

- reduced ECSA and mass activity of ORR catalyst in the presence of 10 and 100 ppm during RRDE experiments

- ammonium species adsorption on Pt leads to a reduction in active sites and causes changes in the kinetic parameters or the reaction mechanisms of the ORR 


\section{Thank you for your attention!}

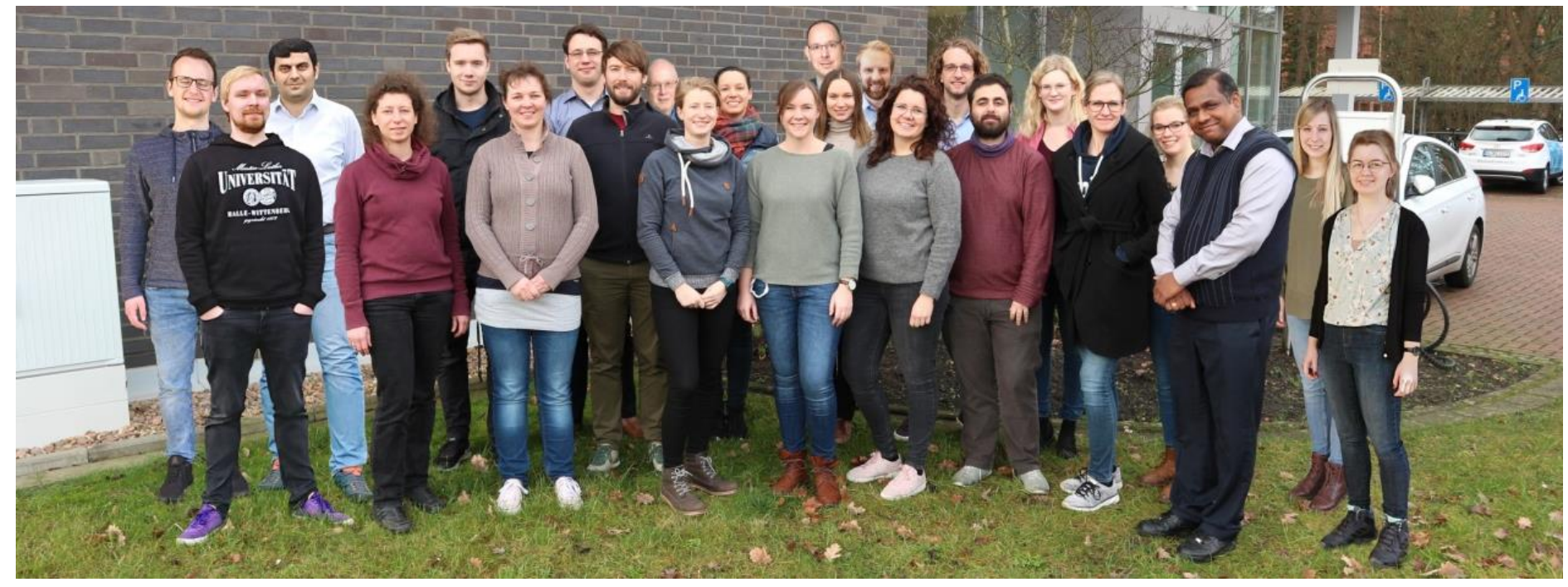

Supported by:

Sederal Ministry for Economic and Energy 


\section{Influence of Ammonia Contamination on HT-PEM Fuel Cell Platinum Catalyst}

A. Dushina, D. Schonvogel, Y. Fischer, J. Büsselmann, A. Dyck, P. Wagner anastasia.dushina@dlr.de PRiME 2020, I01D-2339, 08.10.2020

DLR Institute of Networked Energy Systems, Oldenburg, Germany

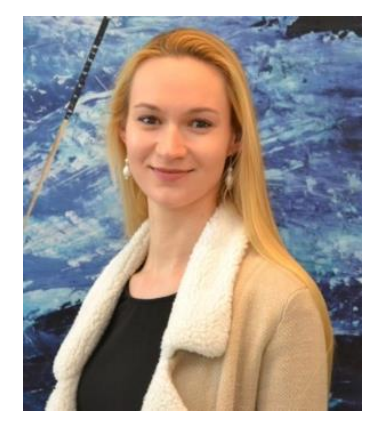

